\title{
LEAN PRODUCTION IMPLEMENTATION ON COFEE BEANS BUSINESS
}

\author{
Nurullaily Kartika ${ }^{1 *}$, Faiz Prawira Setiawan² \\ 1Department of Management, Faculty of Ec onomics and Business, Airlangga University \\ ${ }^{2}$ Department of Agric ultural Engineering and Socio-economic s, Ko be University \\ Address: 1 I I Airlang ga No.4-6 Surabaya \\ 21-1 Rokkodaicho, Nada Ward, Kobe, Japan \\ *E-mail: nurullaily@feb.unair.ac.id
}

\begin{abstract}
The purpose of this study is to a nalyze the application of Lean Production implementation in Kopi Pak Tani. Waste and a big map of the production process originated from Kopi Pak Tani will be used as data. While the big map of the production process is obtained by observation. The background of this research is to achieve a competitive advantage in the production process in order to compete with other competitors. This research applies the qua litative method which consists of 2 different ways for ga ining data. First, data obta ined by the interview process will proceed to the data reduction method, data presentation method, and conclusion determination method. Second, data from observation will through VALSAT Process Activity Mapping Analysis. The results of this study will become a guideline to implement a lean business process by looking at the mapping a nalysis of process activity. Furthermore, from this study, the discovered wastes are in lead time, inventory, defect, and transportation.
\end{abstract}

Keywords: lean, Value Stream Mapping, waste, Proc ess Ac tivity Mapping.

JELClassification: D20, M11

\section{Article History:}

Received :J une 2, 2020; Revised :November 16, 2020; Accepted :November 27, 2020; Available Online : December 6, 2020

DOI: $10.20473 / j m t t . v 13 i 3.19577$

\section{INIRODUCTION}

Efficiency is key to the manufacturing industry. Lean manufacturing improves efficiency, reduces waste, and increases productivity. Lean manufacturing is designed to minimize the waste of material and labor while maintaining or increasing levels of production. These reasons are important for practitioners and scientists to know about lean production's practice in real business.

Coffee becomes one of the most profitable businesses. It proved by a huge number of shops and cafes which have coffee in their menu. In the report from kemenperin.go.id and CNN Ind onesia, the growth of domestic coffee consumption is inc reasing on a verage $7 \%$ per year. Besides, GAEKI (Indonesian Coffee Exporter Association) states that Indonesia has the opportunity to export coffee to the coffee connoisseurs such as the USA, Japan, Austria, Belgium, Norway, and Finland, whose coffee consumption percapita is far above Indonesia, (C2020 Nurulla ily Kartika, Faiz Prawira Setia wan. Published in J umal Manajemen Teori dan Terapan. Published by Universitas Airlangga, Department of Management. This a rtic le is published under the C reative Commons Attribution (CC BY 4.0) lic ence. 
which is only $1.2 \mathrm{kgs}$ per capita/year. Based on those phenomena, the growth of coffee marQ a szket has its op portunity to grow continuously.

Kopi Pak Tani is engaged in manufacturing agribusiness. It was established in 2016 in Surabaya city. This company selecting and processing raw coffee beans (green beans) from famers and change it to roasted beans. Furthemore, the company also grounding coffee beans. Processing workshop is located in the Rungkut area, Surabaya. As a manufacturing company, Kopi Pak Tani has a complex production flow which is starting from processing the coffee fruit (from picking, sorting, washing and fermentation, drying, and reporting processes, which are camied out in the famers' location in Bondowoso district, in order to obta in quality green beans) and then, processing the green beans, which has 5 activities include storing, sieving, roasting, milling, and packaging. Green beans processing activity is completed in Surabaya. The first activity of the production process is storing raw coffee beans that are still in the form of green beans, the second is filtering coffee beans then roasted it when grinding coffee beans become the last process before packing activity.

The a im of the study is to minimize and even avoiding waste. Moreover, the study proposes an improvement in the existing production process which conforms to the principles of lean production.

\section{UTERATURE REVIEW}

\section{Lean Proaduction}

Lean production contributes to waste reduction and business performance improvements. Recently, lean production is also used to lessen inventory costs on a small coffee producer. Lean production aims to achieve and improve effectiveness and efficiency in production. Efficiency through the increasing quality of the product and by reducing all forms of waste in production (Marodin et al., 2018). This is in line with Jacobs and Chase (2018) that state that lean production is all about focusing on how to eliminate waste as much as possible. In the production context, the lean approach is used to achieving production with minimal inventories of raw materials, work-in-process, and finished goods (J acobs and Chase, 2018). Lean Production is not only focused on how to eliminate waste but also focuses on how to add value activities. This is in line with the philosophy of lean production which is based on synchronization (Hoellthaler et al., 2018). Synchronization means the flow of items - including materia Is, information, and customers-, a lways deliver in perfect quality, time, and place (not in the wrong location) (Slack et al., 2013). 


\section{Value Stream Mapping}

Value stream mapping is a tool to understand the current situation and the future condition of business by identifying the flow of material, product, and information and the implementation of lean production. The successful lean implementation was initiated by VSM. VSM ables to eliminate waste in the process, shorten cycle time, and improve product quality greatly. Value stream is a set of actions that bring a specific product through critical management tasks, i.e. problem solving, information management, and physical transformation (Sundar et al., 2014). According to J acobs and Chase (2018), value stream mapping (VSM) is a flowcharting tool used to visualize product flows through various processing steps. In other words, value stream mapping is a graphical way to analyze whether the value is being added or not as materia ls flow through a process. This tool a ims to improve the productivity of the manufacturing system. VSM is also a critical tool to implement the lean approach because it would deepen the work systems understanding that leads to deliver value to the customers and reflecting their perspective (Romero and Arce, 2017). Furthemore, VSM is an effic ient way to identify and eliminate waste (Stadnicka and Litwin, 2019).

VSM consists of standardized symbols. These symbols are categorized as a process, material, information, and general symbols (J acobs and Chase, 2018) VSM has a two-part process, i.e. current state and future state. The current state is a basic view of the current process (a view of all the improvement processes that will be measured) whereas, the future state illustrates the value which is obtained from the improvement activities that have been camied out. The main purpose of making future state is to identify opportunities to design more effic ient and waste-free operating systems.

\section{Process Ac tivity Mapping}

Process Activity Mapping is a key tool to identify lead time, product flows, and information flows. The lean production implementation of the coffee beans business needs to identify process activity in this business. The idea is mapping out every step of activity that occurs throughout a process. Moreover, these data are used to analyze the key problems and understand the causes of these processes in the coffee beans business. Lastly, to fulfill the problem, analysis and action planning development are the final results of this research. Process Activity Mapping (PAM) is one of the tools that belong to the 7 types of Value Stream Analysis Tools (VALSAT) that will be used in this research. PAM will provide an overview of physic al flow and information, the time required for each activity, the distance traveled, and the level of product inventory at each stage of production. Furthermore, PAM could be used to identify which activity includes in VA and NVA (Musyahidah et al., 2015), so the fim will make more suitable strategies to gain profit. The steps of PAM are identifying the value 
stream, identifying waste, considering the rea rangement of flow pattems and other needed activities, and also identify the effects of eliminating some activities (Hardianza, 2016). PAM will give detailed activities and identify whether a process can be rearranged more effic iently.

Value-a dded (VA) is an ac tivity that tra nffo ms raw material or informa tion to meet customer requirements, whereas, non-value a ctivity (NVA) is an activity that does not add value to the product or service itself from the customer perspectives (Voehl et al., 2013). The value is based on the customer's perspectives. An extemal customer is willing to pay value-added activity and not for non-value-added activity. NVA could be eliminated without decreasing the value of the product or services. Some examples of NVA activities are reworking and rewriting reports. NVA activities can be classified in two categories. First, NVA comes from an inadequate design, and the second comes from activities that are not required by the extemal customer or the process.

\section{Waste}

The basic of lean production is to identify and eliminate wastes. Lean production has valueadded and non-value-added. Value-added activities are essential activities that add value to the customers, while non-value-added work or waste is non-essential activities that add time, effort, cost but no value. Waste can be defined as any activity which does not add value. In Japanese words, this waste can be called Muda. Muda means waste or any activity (such as rework and waiting time) that customer is not willing to pay. Slack et al (2013) state that Toyota has identified seven types of waste, and those are over-production, Waiting time, transport, process, inventory, motion, and defectives. Firstly, over-production can be defined as producing more than is immediately needed by the next process or the end customer. This often happens when the fim engages more resources to deliver to the customer (Voehl et al., 2013). It will affect some problems such as extra workers, machines, energy, material, etc, and all of them will increase the cost. Secondly, waste in time can occur when the employees have to wait for the material to the delivered or waiting machine to process, or in the other word, these wastes come from equipment and labor activity. Delays increasing lead time and retention time (Dennis, 2015). Lead time is the time between the customers placing and receiving their order, whereas retention time is processing time in most manufacturing operations. Thirdly, transportation wastes usually come from equipment that is used to move materials such as a forklift, carts, and rolling racks. The wastes could come from some factors, for example, because of poor purchasing practices and inadequate facility layout. Fourthly, the process is the waste could come from poor component design and maintenance. Next, the waste in inventory is related to keeping unnecessary raw materials, parts, and work in process (Dennis, 2015). Furthermore, Voehl et 
al. (2013) state that inventory can appear as finished goods. Moreover, wasted in motion can be categorized in human motion and machine elements. Waste in human motion is related to poor ergonomic design, which affects productivity, quality, and also safety (Dennis, 2015). One of the ways to reduce this waste is by simplific ation. Lastly, defectives are also called quality waste and often very signific ant in operations.

\section{RESEARC H METHODS}

This research method used is a qualitative case study methodology that provides tools for researchers to study complex phenomena in a real-life context. The aim of this study is to answer 'how' and 'why' questions (Yin, 2003). Research on the implementation of lean production strategy on Kopi Pak Tani coffee beans business applies a qualitative approach with observation and interviews method. Data a nalysis techniques, data reduction, and the information were obtained through the observations and interviews from the company. All the interviews were recorded and transcribed immediately afterward. Moreover, data reduction is useful to provide the results of observations clearly in a structured way. Data presented in the form of na ration or chart, the data can be concluded and withdrawn their certa in meaning. The quality of data presentation is very influential to the next steps, as more data are presented clearly. Lastly, the conclusion will be made and re-verified. A valid conclusion is obta inable when the initial conclusion remains consistent even if it has been rereviewed and a new state has been attained.

\section{RESULTS AND DISC USSION}

\section{Identification of Waste Types}

\section{Waiting time}

In the coffee processing business, including Kopi Pak Tani, there are many activities where the operator has to wait before starting new activities. Some activities that require waiting time include heating the fumace for the coffee beans roasting process, cooling the coffee beans, and re-drying the coffee beans if the moisture content on the beans is still too high.

\section{Inventory}

Inventory is paramount in the manufacturing business, especially for companies serving wholesale, both in the preparation of raw materials and stock of finished goods. In Kopi Pak Tani, supplies on display a re still less a vailable to meet the consumers' needs, especially new consumers, so the consumers are forced to delay their purchase and retum on the next day to take their coffee or wait for the coffee to be roasted and sent on the day if they are in urgent. The production capacity, which is not large yet, makes the shipment is done twice when customers order more than 10 kilograms. 


\section{Defects}

At Kopi Pak Tani, there are often raw coffee beans that are unable to pass through the sieving process due to small dirt that is not filtered properly. The step taken to overcome this problem is through manual sorting.

\section{Transportation}

Transportation can tum into waste when there is no systematic delivery planning and ordering SOP to get fresh coffee beans. This is what still happened to Kopi Pak Tani. The company relationship with the consumers or distributors has not been set up in integration so that the shipment sc hedule is still a rguably messy.

\section{Production Process Analysis using Process Activity Mapping}

Process activity mapping is camied out to assess the activities of value-added, non-valueadded, and necessary non-value-added in the entire production process. Below is table 4.2 explaining PAM in the current state:

Table 1

Process Activity Mapping (Current State)

\begin{tabular}{|c|c|c|c|c|c|c|}
\hline No. & Activity Descriptions & Tools & $\begin{array}{l}\text { Distance } \\
\text { (Meters) }\end{array}$ & $\begin{array}{c}\text { Time } \\
\text { (Seconds) }\end{array}$ & $\begin{array}{l}\text { Activity } \\
\text { category }\end{array}$ & $\begin{array}{c}\text { Grading } \\
\text { (VA/NVA/NNVA) }\end{array}$ \\
\hline 1. & Raw materials & Spades, & - & 240 & $\mathrm{~S}$ & NNVA \\
\hline 2. & $\begin{array}{l}\text { retrieval and } \\
\text { weighing } \\
\text { Raw materia ls a re } \\
\text { transferred to sieving } \\
\text { machine }\end{array}$ & $\begin{array}{l}\text { buckets, } \\
\text { scales. } \\
\text { Bucket. }\end{array}$ & 2 & 3 & $\mathrm{Q}$ & NNVA \\
\hline 3. & Sieving process & Sieving & - & 900 & 0 & VA \\
\hline 4. & $\begin{array}{l}\text { Sieved materials are } \\
\text { transferred to } \\
\text { roasting machine }\end{array}$ & $\begin{array}{l}\text { machine } \\
\text { Bucket. }\end{array}$ & 1 & 2 & Q & NNVA \\
\hline 5. & Heating the fumace & - & - & 180 & D & NVA \\
\hline 6. & Roasting process & Roasting & - & 1800 & $\mathrm{O}$ & VA \\
\hline 7. & Cooling beans & machine & 3 & 2100 & $\mathrm{D}$ & NVA NNVA \\
\hline 8. & $\begin{array}{l}\text { Transfering to the } \\
\text { grinding machine }\end{array}$ & $\begin{array}{l}\text { Tray } \\
\text { Tray }\end{array}$ & 3 & 4 & Q & \\
\hline 9. & Weighing & Scales & - & 120 & $\mathrm{O}$ & NNVA \\
\hline 10. & Milling process & Milling & - & 2700 & $\mathrm{O}$ & VA \\
\hline 11. & Packing preparation & $\begin{array}{l}\text { machine } \\
\text { Bucket }\end{array}$ & - & 300 & D & NVA \\
\hline 12. & Packing process & Packages, & - & 240 & $\mathrm{O}$ & VA \\
\hline 13. & $\begin{array}{l}\text { Transfeming to final } \\
\text { storage }\end{array}$ & $\begin{array}{l}\text { Sealing } \\
\text { machine }\end{array}$ & 6 & 60 & $\mathrm{~S}$ & NVA \\
\hline
\end{tabular}

Source: Data processed (2018)

Note: Delay (D), Operation (O), Transportation (T), Storage (S), Inspection (I)

Value Added (VA), Necessary non-Value Added (NNVA), non-Value Added (NVA).

From table 1, it can be observed that there is a delay activity categorized as a non-valueadded activity, which cooling beans activity that takes 35 minutes. Then, there is packing 


\section{Nunullaily Kartika \\ Faiz Prawira Setiawan}

preparation, which is unnecessary to be camied out and can also be included as a delay. The appearance of packing preparation is due to the not strategic laying of equipment. Therefore, it can be redesigned by putting the machines in more strategic places and close to the packing post. Based on the table of process activity mapping current stated above, the calc ulation summary is obta ined as table 2 and 3 expla in below:

Table 2.

Current State PAM Calculation Summary

\begin{tabular}{lcc}
\hline \multicolumn{1}{c}{ Activity } & Number of activities & Time (seconds) \\
\hline Delay (D) & 3 & 2580 \\
Operation (O) & 5 & 5760 \\
Transportation (T) & 3 & 9 \\
Storage (S) & 2 & 300 \\
Inspection (I) & 0 & 0 \\
Total & $\mathbf{1 3}$ & $\mathbf{8 6 4 9}$ \\
\hline
\end{tabular}

Source: Data processed (2018)

Table 3.

Percentage of Current State PAM

\begin{tabular}{lc}
\hline \multicolumn{1}{c}{ Classification of activities } & Number of activities \\
\hline Value added & 4 \\
Non-Value Added & 4 \\
Nec essary non-Value Ad ded & 5 \\
Total & $\mathbf{1 3}$ \\
\% Value Added & $\mathbf{3 0 . 7 \%}$ \\
\% Non-Value Added & $\mathbf{3 0 . 7 \%}$ \\
\% Necessary Non-Value Added & $\mathbf{3 8 . 6 \%}$ \\
\hline
\end{tabular}

Source: Da ta processed (2018)

From table 2, the duration of production time in Kopi Pak Tani takes 8,649 seconds or approximately 2.4 hours. The total activity includes 13 activities. From those 13 activities, delay activity amounts to 3 activities, operation activity calculated to 5 activities, transportation activity amounts to 3 activities, and storage activity is as many as 2 activities. While the inspection activity has not been caried out yet.

From table 3 , it can be detected that from the production process, the percentage of valueadded of $30.7 \%$ equals the percentage of non-value-added of $30.7 \%$ as well. From this data, it can also be concluded that the occuming non-value-added activity is due to the dominance of waiting activities must be reduced or filled with inspection activity that has not been carried out in the production process to minimize the defective products.

After understanding the description of the production process in the current state through process activity mapping, several things should be considered before a ranging PAM design for the future state, which are: 
Table 4.

Process Ac tivity Mapping (Future State)

\begin{tabular}{|c|c|c|c|c|c|c|}
\hline No. & Activity Descriptions & Tools & $\begin{array}{l}\text { Distance } \\
\text { (Meters) }\end{array}$ & $\begin{array}{c}\text { Time } \\
\text { (Seconds) }\end{array}$ & $\begin{array}{l}\text { Activity } \\
\text { category }\end{array}$ & $\begin{array}{c}\text { Grading } \\
\text { VA/NVA/NNVA }\end{array}$ \\
\hline 1. & Raw materials & Spades, & - & 240 & $\mathrm{~S}$ & NNVA \\
\hline 2. & $\begin{array}{l}\text { retrieval and } \\
\text { weighing. } \\
\text { Raw materia ls a re } \\
\text { transferred to sieving } \\
\text { machine. }\end{array}$ & $\begin{array}{l}\text { buckets, } \\
\text { scales. } \\
\text { Bucket. }\end{array}$ & 2 & 3 & Q & NNVA \\
\hline 3. & Sieving process. & Sieving & - & 900 & $\mathrm{O}$ & VA \\
\hline 4. & $\begin{array}{l}\text { Sieved materials are } \\
\text { transferred to roasting } \\
\text { machine }\end{array}$ & $\begin{array}{l}\text { machine. } \\
\text { Bucket. }\end{array}$ & 1 & 2 & Q & NNVA \\
\hline 5. & Heatingthe fumace & - & - & 180 & $\mathrm{D}$ & NVA \\
\hline 6. & Roasting process & Roasting & - & 1800 & 0 & VA \\
\hline 7. & Inspection of roasting & machine. & 3 & 2100 & I & NNVA \\
\hline 8. & $\begin{array}{l}\text { result } \\
\text { Transfering to } \\
\text { grinding machine }\end{array}$ & - & 3 & 4 & Q & NNVA \\
\hline 9. & Weighing & Scales. & - & 120 & $\mathrm{O}$ & NNVA \\
\hline 10. & Milling process. & $\begin{array}{l}\text { Milling } \\
\text { machine. }\end{array}$ & - & 2700 & $\mathrm{O}$ & VA \\
\hline 11. & Packing process & Packages, & - & 240 & $\mathrm{O}$ & VA \\
\hline 12. & Final Inspection & sealing & - & 180 & I & NNVA \\
\hline 13. & $\begin{array}{l}\text { Transfeming to final } \\
\text { storage. }\end{array}$ & machine. & 6 & 60 & $S$ & NVA \\
\hline
\end{tabular}

Source: Data processed (2018)

Note: Delay (D), Operation (O), Transportation (T), Storage (S), Inspection (I)

Value Added (VA), Necessary Non-Value Added (NNVA), Non-Value Added (NVA).

In table 4, points that belong to the category of non-value addedare 2 activities, which are heating the fumace and transfering the finished goods to final storage. From table 4 above of process activity mapping in the future state, it is also obtained a summary of activity calculation and percentage as follows:

Table 5.

PAM Future State Calc ulation Summary

\begin{tabular}{lcc}
\hline \multicolumn{1}{c}{ Activity } & Number of activities & Time (seconds) \\
\hline Delay (D) & 1 & 180 \\
Operation (O) & 5 & 5760 \\
Transportation (T) & 3 & 9 \\
Storage (S) & 2 & 300 \\
Inspection (I) & 2 & 2280 \\
Total & $\mathbf{1 3}$ & $\mathbf{8 5 2 9}$
\end{tabular}

Source: Data processed (2018) 
Table 6.

Percentage of PAM future state

\begin{tabular}{lc}
\hline \multicolumn{1}{c}{ Classification of activities } & Number of activities \\
\hline Value a dded & 4 \\
Non-value added & 2 \\
Nec essary non-value added & 7 \\
Total & $\mathbf{1 3}$ \\
\% Value added & $\mathbf{3 0 . 7} \%$ \\
\% Non-value added & $\mathbf{1 5 . 4 \%}$ \\
\% Necessary non-value added & $\mathbf{5 3 . 9 \%}$ \\
\hline
\end{tabular}

Number of activities

Source: Da ta processed (2018)

From table 5, design for a future state is obtained with a total activity of 13 activities, details as follow: delay a ctivity considers only 1 activity, operational ac tivity a mounts to 5 ac tivities, transportation activity as many as 3 activities, storage activity is calculated to 2 activities, and finally 2 activities of inspection activity. The total production time obtained is 8,529 seconds or approximately 2.37 hours.

In table 6 , the percentage calculation of value-added activities is obtained as many as $30.7 \%$ equals the value of the current state condition. There is a percentage reduction in the non-value-added activities, hence it becomes $15.4 \%$, while there is an addition of magnitudes in the percentage of activities that are necessary non-value-added, therefore it becomes $53.9 \%$

\section{Table 7.}

Comparison of Current State and Future state Production Processes

\% Cument State \% Future State Explanation

Non- $\quad 30.7 \% \quad 15.4 \% \quad$ Percentage in future state is reduced

Valuebecause of cooling beans activities are

Addedca ried out simulta neously with the

Activities inspection, therefore it changes from the beginning of non-value-added a ctivities into nec essa ry-non-va lue-a dded ac tivities, the elimination of packaging preparation by moving tools to more accessible places.

Source: Data processed (2018)

\section{CONCLUSION}

Lean production reduces waste and increases the efficiency of the company's production line, which has a huge impact on the business. The implementation of lean production in Kopi Pak Tani has become one of the examples of how businesses reducing waste and increasing efficiency. The Industrial implic ation of this study is a nalyzing lean production and waste indicators in the coffee sector, and also to understand how business practices and monitors the important variables of the production process in coffee's business. The 
managerial implication is to understand how to improve the intemal flow of companies, operational capability, and adapting to changing intemal and extemal conditions of the company.

The study provides information regarding the waste in Kopi Pak Tani including waiting time, supply, defects, and transportation. The waste of waiting time is due to the heating fumace activity of roasting machines, cooling process, and re-drying. Then, waste of supply occurs because of the absence of SOP that regulates the purchasing process in large quantities of new consumers, so that the supply on display is not able to fulfill the consumers' demand, the waste of defects occurs since there is still small dirt discovered in raw coffee beans that have to go through the sieving process manually, and waste of transportation occurs as a result of waste in supply, which new consumers who suddenly purchase coffee in large quantities urge to be delivered on the same day. However, since supply is not sufficient enough, the rest of the order is forced to be sent on the next day.

Based on the analysis results applying process activity mapping, there is still a lack of inspection activity on the production process. The absence of an inspection process leads to undetectable defects at later days. Also, there is a waste of waiting time that takes quite a time, around 35 minutes in cooling beans activity. Cooling beans activity cannot be eliminated since it will make the coffee packages inflate due to coffee beans still contain gas. It is also observed that the packing preparation time is too long, which lasts for 5 minutes due to the less strategic placement of the equipment. And the implementation of lean production strategy by refeming to the table of process activity mapping in future state whose production process has been modified to become leaner.

In order to minimize waste of waiting time, it is expected to apply the proposed process activity mapping in the future state that has been listed to implement a new activity, which is the inspection of time activity slots that take up waiting time, for example, during cooling beans activity, an inspection of roasted coffee beans can be done concurrently, so that activity that is initially non-value-added becomes necessary non-value-added, and is also useful for detecting defects early. For re-drying a ctivity due to nonstanda rd water content, it requires clear and intensive communic ation during the process of purchasing raw materials at farmers regarding with standardization of raw materials according to the requirement of Kopi Pak Tani, as well as sorting the sourcing of raw materials in order to be well selected to get quality raw materia Is. 


\section{Nunullaily Kartika \\ Faiz Prawira Setiawan}

Intensive communication can be practical in the standard operational procedure (SOP) when signing the business contract of raw materia ls proc urement with fa mers so that actions that contribute to quality reduction can be avoided from the beginning. In minimizing the waste of inventory, it is suggested to create clear and systematic standard operational procedures which regulate the purchasing process in large numbers by new consumers, so that the production process will not be intemupted by the sudden demand in large quantity, this is also camied out so that waste of transportation does not occur. To minimize waste of defects in roasted coffee beans and ground coffee, as well as broken packaging, inspection is suggested to be performed in a series of production processes as planned in the process activity mapping in the future state. Meanwhile, to reduce waste of defects in raw coffee beans, it is possible to do the sourcing selection process of farmers by routine control and the requirement for intensive communication through standard operational procedures starting from contract signing in order to communicate the raw material standards to meet the requirement of Kopi Pak Tani since the beginning of the business.

Suggestions for further research are more in-depth research should be carried out, including the upstream coffee beans process, which post-harvest coffee beans is processing. Later, the application of more diverse lean tools in order to yield more perfect results since they can be observed from various perspectives of theories und enlying them.

\section{REFERENCES}

Dennis, P. 2015. Lean Production Simplified (3rd ed.). CRC Press Ta ylor and Franc is Group.

Hardianza, D. A. 2016. Implementasi Lean Manufacturing dengan Metode Value Stream Mapping pada PT. X. In Master Thesis Intitut Teknologi Sepuluh Nopember: Vol. PM 147501.

Hoellthaler, G., Braunreuther, S., and Reinhart, G. 2018. Digital lean production - An approach to identify potentials for the migration to a digitalized production system in SMEs from a lean perspective. Procedia CIRP 67: 522-527.

Jacobs, F. R., and Chase, R. B. 2018. Operations and Supply Chain Management, 15th edition (15th ed.). Mc Graw Hill Education.

Marodin, G., Frank, A. G., and Tortorella, G. L. 2018. Lean Product Development and Lean Manufacturing: Testing Moderation Effects. Intemational Joumal of Production Economic s 203: 301-310.

Musyahidah, B., Choin, M., and Hamdala, I. 2015. Implementasi Metode Value Stream Mapping sebagai Upaya Meminimalkan Waste. Jumal Rekayasa Dan Manajemen Sistem Industri Vol. 3 No. 2 Teknik Industri Universitas Bra wija ya 3(2). 
Romero, L. F., and Arce, A. 2017. Applying Value Stream in Manufacturing: Applying Value Stream Mapping in A Systematic Literature Review Applying Value Stream Mapping in Manufacturing: Applying Value Stream Mapping in A Systematic Review Applying Value Stream Literature Mapping in Manu. IFAC-PapersO nLine 50(1): 1075-1086.

Slack, N., Jones, A. B., and Johnston, R. 2013. Operations Management, 7th edition. In Pearson Education Limited (7th ed.). Pearson Educ ation Limited.

Stadnicka, D., and Litwin, P. 2019. Value Stream Mapping and System Dynamics Integration For Manufacturing Line Modelling and Analysis. Intemational Joumal of Production Economic s 208: 400-411.

Sundar, R., Balaji, A. N., and Satheesh Kumar, R. M. 2014. A review on lean manufacturing implementation techniques. Procedia Engineering 97: 1875-1885.

Voehl, F., Hamington, H. J., Mignosa, C., and Chamon, R. 2013. The lean six sigma black belt handbook: Tools and methods for process acceleration. In The Lean Six Sigma Black Belt Handbook: Tools and Methods for Process Acceleration. 